\title{
Cerasus microcarpa and Amygdalus scoparia Methanolic Extract Protect Cultured Cerebellar Granule Neurons Against $\beta$-amyloid-induced Toxicity and Oxidative Stress
}

\author{
Nasim Ataei ${ }^{1}(\mathbb{D})$, Maliheh Soodi*1(D), Homa Hajimehdipoor ${ }^{2,3}$ (D), \\ Sholeh Akbari ${ }^{1}$ (i), Mahshid Alimohammadi ${ }^{1}$ (iD
}

1. Dept. of Toxicology, Faculty of Medical Sciences, Tarbiat Modares University, Tehran, Iran

2. Traditional Medicine and Materia Medica Research Center, Shahid Beheshti University of Medical Sciences, Tehran, Iran

3. Dept. of Traditional Pharmacy, Faculty of Traditional Medicine, Shahid Beheshti University of Medical Sciences, Tehran, Iran

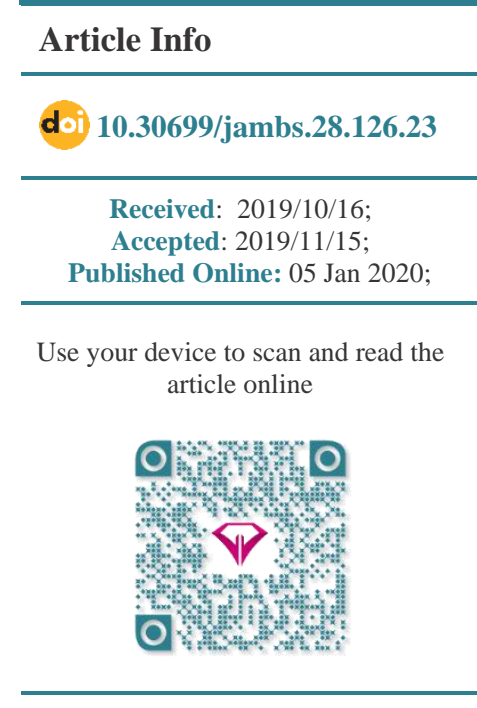

Corresponding Information: Maliheh Soodi, Dept. of Toxicology, Faculty of Medical Sciences, Tarbiat Modares University, Tehran, Iran E-Mail: $\underline{\text { soodi@modares.ac.ir }}$

\begin{abstract}
Background \& Objective: Beta-amyloid peptide (A $\beta$ ) causes neural cell death and has a pivotal role in the progression of Alzheimer's disease (AD). The prevention of $A \beta$-induced toxicity is a target for agents intend to treat Alzheimer's disease. Our previous in vitro study indicated anti-cholinesterase and anti-oxidant activity of Amygdalus scoparia and Cerasus microcarpa methanolic extracts. In the present study, their neuroprotective effects against $A \beta$-induced toxicity are investigated.

Materials \& Methods: The methanolic extracts of the aerial parts of A. scoparia and $C$. microcarpa were prepared by the maceration method. In the culture, mature cerebellar granule neurons (CGNs) were exposed to $A \beta$ alone or in combination with different concentrations of extracts and incubated for 24 hours, and cell viability was measured by the MTT assay. Oxidative stress markers and AChE activity were also measured. Then, the AChE activity of cultured neurons was measured after incubation with different concentrations of extracts. The LD50 values of extracts were estimated using the limit test.
\end{abstract}

Results: The co-incubation of $C$. microcarpa and A. scoparia extracts with $\mathrm{A} \beta$ protected $C G N$ s against $A \beta$-induced cell death and ameliorated $A \beta$-induced oxidative stress. The AChE activity of cultured neurons was inhibited by both extracts in a dosedependent manner. LD50 was estimated as being above $2000 \mathrm{mg} / \mathrm{kg}$ for both extracts.

Conclusion: Both extracts attenuated $A \beta$-induced cell death by ameliorating oxidative stress. Also, the inhibitory effect of extracts on AChE activity might have been involved. Based on these results, these extracts may have therapeutic effects on Alzheimer's disease. However, further investigations are recommended.

Keywords: Alzheimer's disease, Amygdalus scoparia, Cerasus microcarpa, Oxidative stress

(c) (1) (-) Copyright $\odot$ 2020, This is an original open-access article distributed under the terms of the Creative Commons Attribution-noncommercial 4.0 International License which permits
copy and redistribution of the material just in noncommercial usages with proper citation.

\section{Introduction}

Alzheimer's disease (AD) is a common kind of dementia in older people. It is characterized by the gradual worsening in cognitive functions, behavioral changes, and a deterioration of daily living activities. $\mathrm{AD}$ is characterized by the presence of senile plaques, which mainly consist of extracellular beta-amyloid $(\mathrm{A} \beta)$ peptide deposits and intracellular neurofibrillary tangles (NFTs), which are abnormal hyperphosphorylated tau protein aggregates. These pathological findings are associated with a loss of cholinergic fibers and inflammatory responses such as reactive gliosis $(1,2)$.
The major pathological hallmark of $\mathrm{AD}$ is the abnormal aggregation of $A \beta$ peptides in the brain. $\mathrm{A} \beta$ monomers tend to aggregate and produce extracellular $A \beta$ deposits (3). Studies have indicated that the aggregated form of $\mathrm{A} \beta$ is toxic to neurons. Oxidative stress and mitochondrial dysfunction, which lead to apoptotic cell death, inflammatory responses, and the disturbance of energy metabolism homeostasis, are some mechanisms that progress AD. Moreover, A $\beta$ peptide has a pivotal role in initiating these mechanisms (4). 
Studies have shown that $A \beta$ peptide can generate free radicals and induce oxidative stress (5). Supporting evidence from a variety of in vitro and in vivo studies confirm that oxidative stress has a fundamental role in the pathogenesis of $\mathrm{AD}$ and that free radicals are responsible for mediating neuron degeneration and death (6). Therefore, antioxidant compounds can prevent AD progression (7). Studies have indicated that antioxidants from medicinal plant sources reduce $A \beta$ induced oxidative stress $(\mathbf{8})$.

The destruction of cholinergic neurons, followed by a decrease in the amount of the acetylcholine (Ach) neurotransmitter, is one of the hallmarks of $\mathrm{AD}$. One approach for the treatment of $\mathrm{AD}$ is inhibiting the acetylcholinesterase (AChE) enzyme. AChE inhibitors raise the level of acetylcholine in the brain and relieve $\mathrm{AD}$ symptoms but cannot cure or prevent the disease (9). Due to the complex nature of $\mathrm{AD}$, monotherapy is not effective in $\mathrm{AD}$ treatment. Therefore, the current research focused on multi-targeted drugs as disease-modifying drugs that interfere with the disease progression through various mechanisms (10). Medicinal plants contain several biologically active compounds and are useful in the treatment of complex diseases. Therefore, medicinal plants are the focus of researchers' attention as a source of new $\mathrm{AD}$ therapies (11).

A. scoparia Spach and C. microcarpa (C. A. Mey.) Boiss. are plants from the Rosaceae family. Plants from the Rosaceae family have been used as ancient and traditional medicines in many countries (12). These plants show a variety of biological effects. They are rich in phenolic compounds that prevent the progression of AD (13). A. scoparia Spach is endemic to Iran. Various parts of this plant, including its oil, leaves, and gum, are frequently used in traditional medicine and industries. Almond syrup relieves coughs, the leaves can be used as laxatives, and its decoction is a remedy for liver and gallbladder failure. The resin from this plant has been used in medicinal products as antipyretics and for appetite stimulation. Also, its anti-diabetic effect for hexan extraction has been reported (14-16). Furthermore, studies show that this plant inhibits AChE enzyme (17).

C. microcarpa grows in Iran. This plant contains alkaloids, tannins, and polyphenol compounds. The roots and fruit of this plant are traditionally used as an anti-flatulent and for pain relief in the digestive system (14). Although this plant has been widely used in Iran, its pharmacological effects have not been adequately studied, and there are only a few studies that show the antioxidant and AChE inhibitory effects of $C$. microcarpa (17). Furthermore, in a previous study, we indicated the protective effect of this extract against $A \beta$-induced toxicity in PC12 cells (18). In the present study, the protective effects of Amygdalus scoparia and Cerasus microcarpa in primary neuron culture and their possible mechanisms were investigated.
The primary culture of cerebellar granule neurons (CGNs) is a proper in vitro model in neuroscience for studying molecular and cellular mechanisms of neural cell death and survival. This model has been frequently used for the assessment of mechanisms involved in neurodegeneration and neuroprotection. These cells develop after birth; then they can be easily isolated and cultured. After plating, these cells differentiate to neurons and produce a homogeneous population of neurons, which makes this a good study model (19). The CGNs culture has been used for studying the protective effect of a new compound against $A \beta$ induced neurotoxicity $(\mathbf{2 0 , 2 1 )}$.

\section{Materials and Methods}

\section{Materials}

Dulbecco's modified Eagle's Medium (DMEM), penicillin-streptomycin $(10,000 \mathrm{U} / \mathrm{mL})$, fetal bovine serum (FBS), and trypsin (\%0.25) were purchased from GIBCO (USA). Poly-D-lysine (PDL) was obtained from Santa Cruz Biotechnology (USA). Betaamyloid peptide (AB 25-35) was taken from Enzo life sciences (USA). All other materials were obtained from Sigma (USA).

\section{Plant Material}

Aerial parts of $C$. microcarpa and A. scoparia were collected from Hamadan and Kohgiluyeh Va Boyer Ahmad provinces of Iran, respectively. The plants were recognized by the botanists, and their voucher specimens were placed at Herbarium of Traditional Medicine and Materia Medica Research Center (TMRC), Shahid Beheshti University of Medical Sciences (TMRC) (No. 3259 TMRC and No. 2343 TMRC, for Amygdalus scoparia and Cerasus microcarpa, respectively).

\section{Plants Extraction}

The total extract of the aerial parts of the collected plants was obtained using the maceration method after drying in shade and grounding. $100 \mathrm{~mL}$ of methanol:water $(80: 20)$ was added to $10 \mathrm{~g}$ of the plant powder, and then every $24 \mathrm{~h}$, the mixture was filtered, and the fresh solvent was added. This procedure was continued for three days. Finally, all extracts were pooled and their solvent was evaporated by a rotary evaporator, then the resultant concentrate was dried using a freeze drier.

\section{Measurement of Total Phenolic Compounds}

The Folin-Ciocalteu spectrophotometric method was used for the measurement of the total phenolic contents of the extracts, and Gallic acid was used as the standard. Folin- Ciocalteu's reagent was mixed with a methanolic solution of the extracts or Gallic acid and incubated at $22^{\circ} \mathrm{C}$ for 5 minutes. After the addition of sodium carbonate $(7 \%)$, the reaction mixture was incubated at $22^{\circ} \mathrm{C}$ for 90 minutes. Then the absorbance 
of the mixture was measured at $725 \mathrm{~nm}$. The amount of total phenolic compounds of extracts was stated as Gallic acid equivalent, which has been expressed in milligram per $100 \mathrm{~g}$ dried extract.

\section{Primary Culture of Cerebellar Granule Neurons}

We isolated cerebellar granule cells from postnatal mice (BALBc) and cultured those, as previously described (22). Briefly, cerebella were dissected from mice neonates (6-7 days old, BALB/c) and digested with trypsin. Then the single-cell suspension was obtained by triturating. After that, the single cells were cultured in cell culture plates coated by PDL. The culture medium was DMEM containing $4.5 \mathrm{~g} / \mathrm{L}$ glucose, $25 \mathrm{mM} \mathrm{KCl}$, insulin $(100 \mathrm{mU} / \mathrm{L})$, and $10 \%$ FBS. We added the cytosine b-D-arabinofuranoside (Ara-C) $48 \mathrm{~h}$ after cell seeding, to the cell culture medium $(20 \mu \mathrm{M}$ final concentration in medium), and thereby non-neuronal cell growth was inhibited. Because cerebellar granular cells condition the medium during growth and differentiation, the medium was not changed. After seven days of in vitro (DIV 7), more than $95 \%$ of cells in culture were identified as neurons characterized by MAP2 protein immunostaining. All animal experiment procedures were approved by The Medical Ethics Committee of Tarbiat Modares University (Ethical code: IR.TMU. REC.1394.178).

\section{Treatment}

To measure the protective effect of extracts against $\mathrm{A} \beta$-induced toxicity, we cultured CGNs onto PDL coated 96 well plate $\left(1 \times 10^{5} \mathrm{cell} /\right.$ well $)$ and incubated the mature neurons on DIV 7 , with $10 \mu \mathrm{M} \mathrm{A} \beta$ in aggregated form alone or in combination with different concentrations of extracts $(5-100 \mu \mathrm{g} / \mathrm{mL})$ for 24 hours; then the cell viability was measured by MTT assay. The powder of $A \beta 25-35$ peptide was reconstituted in sterile water to obtain a final concentration of $1 \mathrm{mM}$. Aliquots of this solution were incubated at $37^{\circ} \mathrm{C}$ for 72 $\mathrm{h}$ to establish the aggregated form of $\mathrm{A} \beta$ peptide. We prepared the stock solutions of the extract by dissolving them in DMSO, and then the stock solution was diluted with culture medium so that the final concentration of DMSO in the medium was $0.5 \%$ or less $(20)$.

\section{MTT Assay}

The methyl tetrazolium salt (MTT) reduction assay is a common assay for measurement of the percent of surviving neurons. The assay is based on the reduction of yellow tetrazolium salt (MTT) by the mitochondrial dehydrogenases of live cells, which produced the formazan metabolite with purple color. After incubation time, the culture medium was discarded, then the fresh medium containing MTT $(0.5 \mathrm{mg} / \mathrm{mL}$ final concentration) was added. After $4 \mathrm{~h}$ incubation in a $\mathrm{CO}_{2}$ incubator at $37^{\circ} \mathrm{C}$, the medium was removed, and $100 \mu \mathrm{L}$ DMSO was added, and the plate was shaken for 5 minutes for dissolving the formazan crystals. We measured the absorbance at $570 \mathrm{~nm}$ against $630 \mathrm{~nm}$ as the reference wavelength. The viability of treated cells is expressed as a percentage of control (23).

\section{Measurement of ROS}

The fluorescent probe 2, 7 dichlorodihydrofluorescein diacetate (DCFH-DA) is frequently used for the measurement of ROS produced during the oxidative stress. This probe easily penetrates into cells and is deacylated by deacetylase enzymes to produce DCFH. Following that, ROS could reduce DCFH to DCF that has measurable fluorescent intensity (Excitation: $488 \mathrm{~nm}$, Emission $525 \mathrm{~nm}$ ). Mature neurons on DIV 7, seeded onto PDL coated 96-well plate, were incubated with $10 \mu \mathrm{M} A \beta$ alone or in combination with each extract at the concentration of $75 \mu \mathrm{g} / \mathrm{mL}$. After the incubation time ended, we removed the culture medium from the all wells and added a fresh medium containing DCFH-DA $(10 \mu \mathrm{M})$, then the culture was further incubated for 17 minutes. We measured the DCF fluorescence intensity using fluorescence plate reader (BioTek, United States) (24).

\section{Measurement of Glutathione Peroxidase (GPx) Activity}

We detected the GPx activity in CGNs by the colorimetric kit (BioVision). We plated CGNs on PDL coated 6 -well plates $\left(3 \times 10^{6}\right.$ cell/well $)$ and incubated them with $A \beta$ peptide $(10 \mu \mathrm{M})$ alone or in combination with each extract $(75 \mu \mathrm{g} / \mathrm{mL})$, on DIV 7 , for $24 \mathrm{~h}$. We removed the medium after the incubation time, harvested cells, and then homogenized the collected cells in PBS. We centrifuged the homogenate at $1000 \mathrm{~g}$ for $10 \mathrm{~min}$ and kept the supernatant for enzyme activity and protein assay. The protein of samples were quantified using the Bradford method (25).

\section{Acetylcholinesterase Activity Assay}

For evaluating the effect of extracts on AChE activity of CGNs, mature CGNs on DIV 7 were incubated with different concentrations of each extract for $24 \mathrm{~h}$. Also, the AChE activity of CGNs was measured after incubation of mature CGNs on DIV 7 with $A \beta$ alone or in combination with each extract $(75 \mu \mathrm{g} / \mathrm{mL})$ for $24 \mathrm{~h}$. After the incubation, we collected the cells, then homogenized them in PBS and centrifuged the homogenate at $1000 \mathrm{~g}$ for $10 \mathrm{~min}$. We kept the supernatant for enzyme activity and protein assay. We used Elman's method for measuring AChE activity (26). Briefly, Elman's reagent was prepared by mixing phosphate buffer $(\mathrm{pH}=8,0.1 \mathrm{M})$, ATCh $75 \mathrm{mM}$ as a substrate, and Di- thio- nitro-benzoic acid (DTNB) 10 $\mathrm{mM}$ in a ratio of $150: 2: 5$. This reagent $(100 \mu \mathrm{L})$ was transferred to the each well of 96-well plate. After adding $50 \mu \mathrm{L}$ supernatant, the absorbance was immediately measured at $405 \mathrm{~nm}$ for $15 \mathrm{~min}$, and whereby the rate of enzyme activity was calculated.

\section{LD50 Estimation}

The LD50 was estimated by the limit test method according to the OECD protocol $(27,28)$. As stated by this protocol, one female mouse was orally 
administered a single dose of $2000 \mathrm{mg} / \mathrm{kg}$ of each extract by gavage, and the animal was monitored for 48 hours. Since the first mouse survived, four additional mice received the same dose of $2000 \mathrm{mg} / \mathrm{kg}$ by gavage, sequentially. If three or more animals survived, the LD50 value was estimated over $2000 \mathrm{mg} / \mathrm{kg}$, and the test substance was considered safe. We evaluated all animals for 14 days in terms of mortality, apparent health, and weight.

\section{Statistical Analysis}

The statistical analysis was done by Graph-Pad Prism7 software. Each data represented the Mean \pm SEM of three separate experiments. Statistical differences were estimated by one-way ANOVA analysis followed by Tukey's Multiple Comparison Test. We considered $P<0.05$ as a significant level.

\section{Results}

\section{Amount of Total Phenolic Compounds in the Extracts}

The data for measuring the total phenol content of the extracts were obtained from the calibration curves of Gallic acid $\left(y=2.6 x-0.038, \quad r^{2}=0.99\right)$, which was established by the Folin-Ciocalteu method. The amount of total phenolic compounds in the extracts were $14.6 \pm 0.26$ and $6.1 \pm 0.15 \mathrm{mg}$ Gallic acid in $100 \mathrm{gr}$ dried extract for $C$. microcarpa and A. scoparia, respectively.

Protective Effects of $C$. microcarpa and $A$. scoparia Extracts on A $\beta$ - induced Cytotoxicity

Figures $1 \mathrm{~A}$ and $1 \mathrm{~B}$ show the Effects of $C$. microcarpa and A. scoparia extracts on $\mathrm{A} \beta$ - induced cytotoxicity in cultured CGNs, respectively. Incubation of CGNs with $\mathrm{A} \beta(10 \mu \mathrm{M})$ for $24 \mathrm{~h}$ significantly decreased the cell viability $(P<0.001)$. A $\beta$-induced cytotoxicity was dose-dependently reduced by co-treatment of the CGNs with different concentrations of extracts and was entirely resolved at a concentration of $75 \mu \mathrm{g} / \mathrm{mL}$ or above. In Figure $1 \mathrm{C}$, the protective effect of extracts on the $A \beta$-induced cytotoxicity in CGNs has been compared with the protective effects of memantine, BHT, and donepezil. The results revealed that both extracts had a more protective effect than memantine, BHT, and donepezil. Treatment of CGNs with extracts alone at a concentration range of $5-100 \mu \mathrm{g} / \mathrm{mL}$ did not affect the cell viability (data not shown).

Effect of $C$. Microcarpa and A. scoparia on ROS Production
The generation of ROS was measured by the fluorimetric method. Figure 2 gives information about ROS production in the studied groups. A significant increase in fluorescence intensity following $A \beta$ treatment indicated that $\mathrm{A} \beta$ induced ROS production in CGNs. When CGNs were co-incubated with $\mathrm{A} \beta$ and $C$. Microcarpa or $\mathrm{A} \beta$ and A. scoparia extract, the fluorescence intensity significantly decreased, indicating the protective effect of extracts on $\mathrm{A} \beta$ induce ROS production in CGNs.

Effect of $C$. microcarpa and A. scoparia on GPx Activity

GPx is the most important antioxidant enzyme in neural cells. Results indicated that the incubation of CGNs with A $\beta$ significantly reduced the GPx activity comparing to that of the control group. While the cells were coincubated with $A \beta$ and extracts, reduction of GPx activity by $A \beta$ was prevented, and the decrease in GPx activity was not observed in these groups (Figure 3).

Effect of C. microcarpa and A. scoparia on AChE Activity

Figures $4 \mathrm{~A}$ and $\underline{4 \mathrm{~B}}$ show the effect of different concentrations of $C$. microcarpa and A. scoparia extracts $(5-100 \mu \mathrm{g} / \mathrm{mL})$ on AChE activity in CGNs, respectively. Both extracts dose-dependently decreased the AChE activity, but $C$. microcarpa extract decreased the AChE activity more effectively than $A$. scoparia.

Also, AChE activity in CGNs after incubation with $\mathrm{A} \beta$ alone and in combination with extracts was measured. The results are shown in Figure 4C. Treatment of CGNs with $\mathrm{A} \beta$ for $24 \mathrm{~h}$ significantly increased the AChE activity, and co-treatment with extract attenuated AChE activity increment.

\section{LD50 TEST}

The LD50 was estimated by the limit test method according to the OECD protocol. All the five mice treated with $2000 \mathrm{mg} / \mathrm{kg}$ of each extract survived. Treated animals were observed for 14 days. Signs of toxicity were not observed during the monitoring period. Also, significant abnormal body weight changes were not observed between extract-treated and control groups. Based on these findings, the LD50 value was estimated at over $2000 \mathrm{mg} / \mathrm{kg}$ for both extracts; therefore, extracts were considered safe. 
A

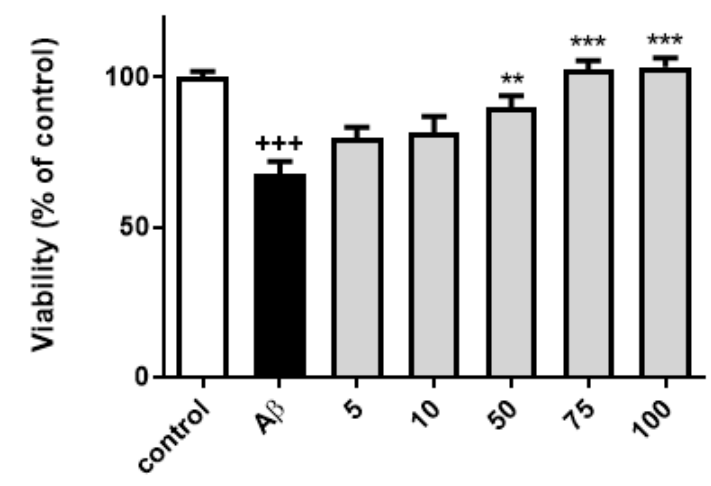

Extract con. $(\mu \mathrm{g} / \mathrm{ml})+A \beta(10 \mu \mathrm{M})$
$\mathbf{B}$

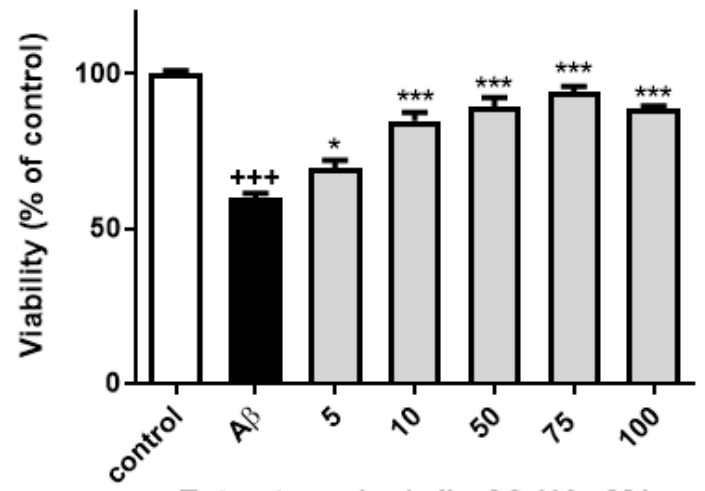

Extract con. $(\mu \mathrm{g} / \mathrm{ml})+A \beta(10 \mu \mathrm{M})$

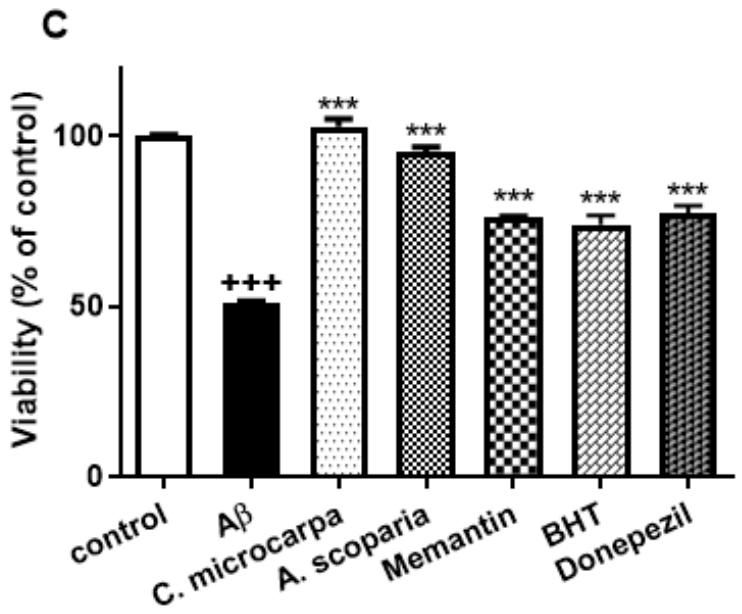

Figure 1. Effects of the Cerasus microcarpa and Amygdalus scoparia extracts on A $\beta$-induced cytotoxicity in cerebellar granule neurons (CGNs) culture. (A) Cerasus microcarpa, (B) Amygdalus scoparia, (C) protective effects of extracts, Donepezil, Memantine, and BHT. $+++P<0.001$ vs. control, $* P<0.05, * * P<0.01$, and $* * * P<0.001$ vs. A $\beta$-treated group.

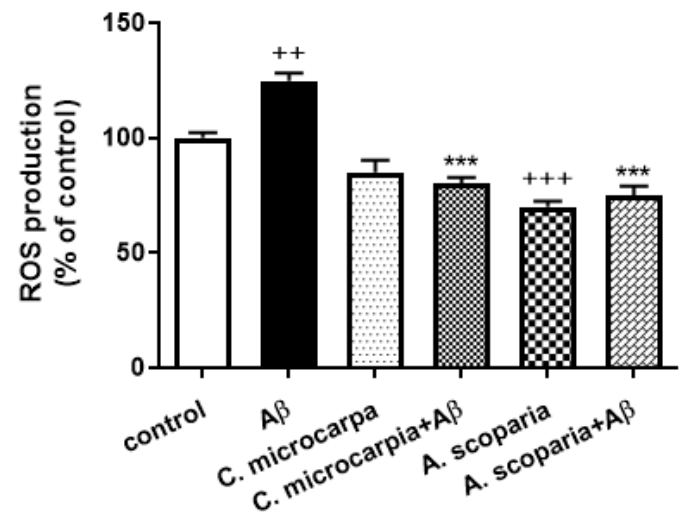

Figure 2. ROS production in CGNs culture, $+++P<0.001$ vs. control $* * * P<0.01$, *** $P<0.001$ vs. A $\beta$-treated group.

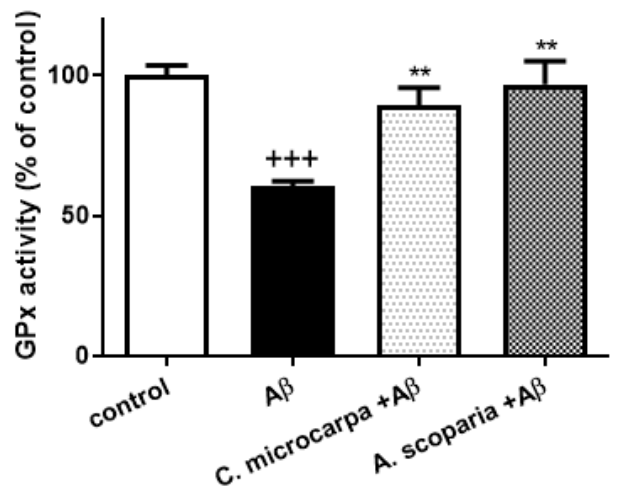

Figure 3. Glutathion peroxidase (GPx) activity in CGNs culture. $+++P<0.001$ vs. control, ** $P<0.01$ vs. A $\beta$-treated group. 
A

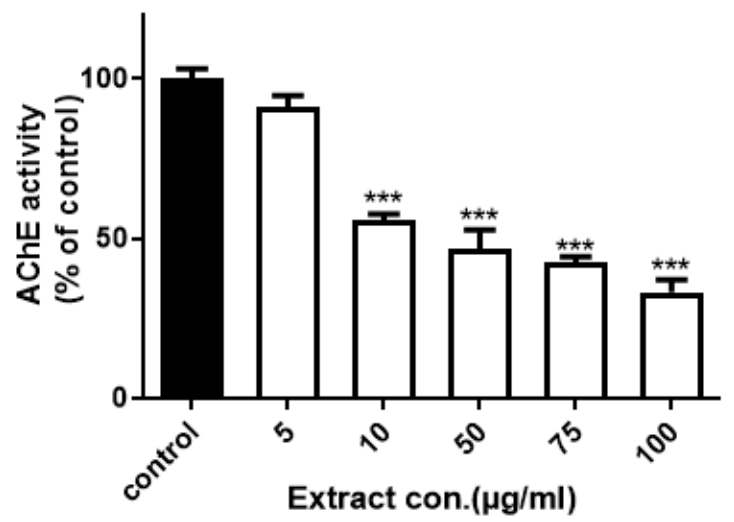

B

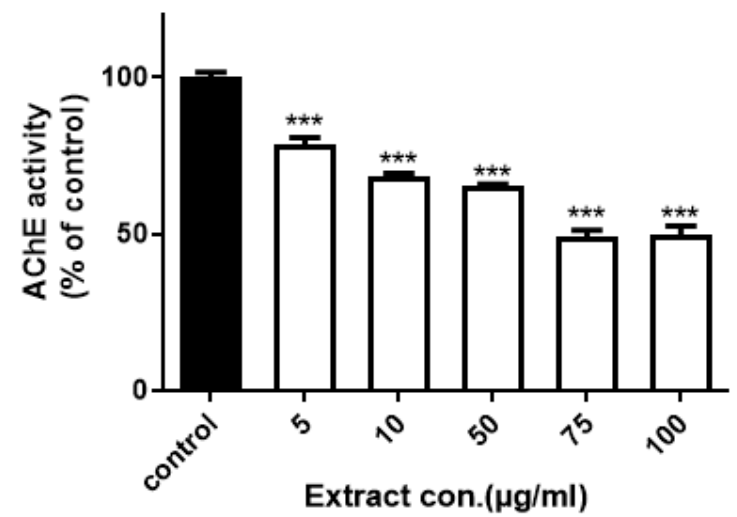

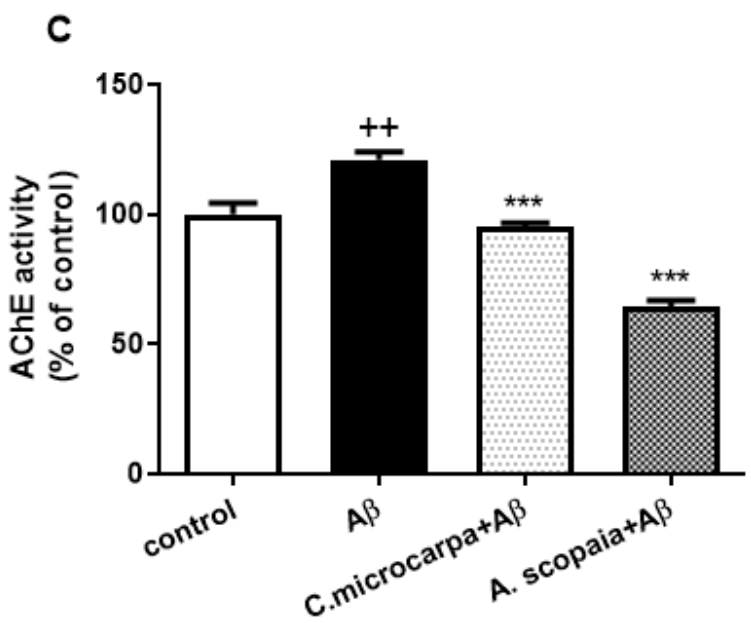

Figure 4. Acetylcholinestrase (AChE) activity in cultured CGNs. (A) Effect of different concentrations of Cerasus microcarpa extract on CGNs AChE activity. (B) Effect of different concentrations of Amygdalus scoparia extract on CGNs AChE activity. (C) Effect of $A \beta$ alone or in combination with extracts on AChE activity in CGNs culture. $+p<0.01 v s$. control, $* * * P<0.001$ vs. A $\beta$-treated group.

\section{Discussion}

In this study, the neuroprotective effects of Cerasus microcarpa and Amygdalus scoparia against A $\beta$ induced toxicity were evaluated, and the results indicated that both extracts dose-dependently prevent A $\beta$-induced cell death.

Previous studies have shown that oxidative stress is a well-known mechanism initiated by $\mathrm{A} \beta$ and an essential mechanism in $A \beta$-induced cell death (6). The results of our study also showed that the incubation of CGNs with $\mathrm{A} \beta$ reduced the viability of cells, which was associated with increased ROS levels and decreased GPx activity as an antioxidant enzyme. Thus, it is suggested that cell death after CGN exposure with $A \beta$ is mediated through an oxidative stress mechanism. Furthermore, our results indicated that $\mathrm{A} \beta$-induced oxidative stress and cell death were attenuated by the co-treatment of $C$. microcarpa and $A$. scoparia methanolic extracts. Therefore, the antioxidant activity of these extracts is likely involved in their neuroprotective activity.

Although C. microcarpa and A. scoparia are widely used in Iranian traditional and folk medicine, their pharmacological and therapeutic effects have not been studied very much, and there is not much information about their constituents. Our previous study indicated that $C$. microcarpa extract protects against $\mathrm{A} \beta$-toxicity in PC12 cells (18), and a study by Hajimehdipoor et al. showed that the methanolic extracts of these plants exhibit antioxidant and anticholinesterase activity (20). These plants belong to the Rosacea family, and plant species in this family are rich in polyphenolic and flavonoid compounds with potent antioxidant activity. The results of the present study showed that $C$. microcarpa and A. scoparia extracts have $14.6 \pm 0.26$ and $6.1 \pm 0.15 \mathrm{mg} / \mathrm{g}$ dried extract total phenol content, 
respectively, which indicates a high level of phenolic compounds for these extracts.

Polyphenols are potent free radical scavenging agents, meaning that they reduce ROS levels in cells, thus protecting the cells from oxidative insults. However, recent studies have involved other mechanisms in polyphenol antioxidant activity and neuroprotection beyond direct free radical scavenging activity (29). Some natural polyphenols exhibit mitoprotective activity and directly interact with mitochondrial biomolecules. In this way, they prevent mitochondrial membrane permeabilization and, in turn, inhibit the apoptotic process initiated from mitochondria. The mitochondrial apoptosis pathway is involved in $A \beta$ induced toxicity and is ameliorated by polyphenols such as rosmarinic acid (30).

In addition, polyphenols such as resveratrol increase mitochondrial biogenesis and protect neurons against A $\beta$-induced toxicity (31). Polyphenols also promote the survival of neurons via neurotrophic factor (NTF)-like activity. Lipophilic polyphenols such as curcumin and resveratrol can cross the blood-brain barrier and induce NTF gene expression (e.g., brain-derived neurotrophic factor (BDNF)) (29). It has been reported that BDNF protects neurons against $A \beta$-induced toxicity (32). Also, some polyphenols activate NTF signal transduction by binding to NTF receptors or to downstream proteins and enzymes. Other mechanisms that are involved in polyphenol neuroprotective activity include the activation of prosurvival signal pathways such as PI3K/AKT and PKC (33). Overall, studies have indicated that polyphenols protect neurons through different mechanisms that inhibit death signals.

The results of our study showed that CGN exposure with different concentrations of $C$. microcarpa and $A$. scoparia extracts for $24 \mathrm{~h}$ reduced AChE activity. The results indicated that both extracts inhibit AChE activity in CGNs, as the previous study reported in vitro AChE inhibitory activity for these extracts (17). Several plant secondary metabolites with diverse chemical structures-including alkaloids, terpenes, and polyphenolic compounds-have AChE inhibitory effects (34). Some polyphenolic compounds such as rosmarinic acid, quercetin, and rutin, which are found in the rosacea family, also have AChE inhibitory effects (35). C. microcarpa and A. scoparia extracts are rich in phenolic compounds, which can contribute to the AChE inhibitory effect of these extracts.

Studies have indicated that natural AChE inhibitors improve memory deficits in animal models of $\mathrm{AD}$ and prevent $A \beta$-induced toxicity in cell cultures. The inhibition of $\mathrm{AChE}$ increases Ach levels in the brain and improves the cholinergic deficit, thus improves the cognitive function of $\mathrm{AD}$ patients (36). On the other hand, bounded $\mathrm{AChE}$ protein with $\mathrm{A} \beta$ peptide has been found abundantly in amyloid plaques, and AChE activity increases nearby the amyloid plaques in the $\mathrm{AD}$ brain (37). It has been shown that $\mathrm{A} \beta$ binds to the peripheral anionic site of AChE proteins (38). Attaching $\mathrm{AChE}$ proteins to $\mathrm{A} \beta$ promotes $\mathrm{A} \beta$ aggregation. Also, the AChE-A $\beta$ complex is more neurotoxic than $A \beta$ alone (39), and so the compounds that bind to the peripheral anionic site of $\mathrm{AChE}$ proteins inhibit $A \beta$ binding and prevent $A \beta$ aggregation and toxicity. Polyphenolic compounds such as flavonoids act as non-competitive inhibitors of AChE by binding to the peripheral anionic site (35). It is therefore suggested that phenolic compounds prevent neurons against $A \beta$-induced toxicity by inhibiting $\mathrm{AChE}$ and preventing $\mathrm{A} \beta-\mathrm{AChE}$ complex production.

The present study indicated that the treatment of CGNs with $\mathrm{A} \beta$ increased AChE activity and that cotreatment with both $C$. microcarpa and A. scoparia extracts could attenuate it. In vitro studies have indicated that AChE activity increases in cultured neuronal cells that have been exposed to $A \beta$ peptides (20). Similarly, the injection of $A \beta$ peptides in the brain of experimental animals increased AChE activity associated with learning and memory deficits (40).

The mechanisms by which $A \beta$ increases $A C h E$ activity have not been clearly identified. $A \beta$-induced oxidative stress and the disruption of calcium homeostasis might be involved (41). It has been reported that oxidative stress increases AChE activity and upregulates $A C h E$ gene expression, which was ameliorated by antioxidant compounds (42). Some medicinal plant extracts (without the AChE inhibitory effect but with potent antioxidant activity) attenuate $A \beta$-induced elevated AChE activity by improving the oxidative stress condition in the cell culture or the brain $(40,43)$. Thus, it is suggested that $C$. microcarpa and A. scoparia extracts decrease elevated AChE activity by coping with oxidative stress.

The LD50 values of extracts were estimated by the limit test. The results indicated that the LD50 values of both extracts were greater than $2000 \mathrm{mg} / \mathrm{kg}$. Weight loss and signs of illness were not observed during the 14 days of monitoring mice after extract treatment. Also, based on the OECD protocol, they were considered non-toxic compounds. 


\section{Conclusion}

In this study, we indicated that $C$. microcarpa and $A$. scoparia extracts improve A $\beta$-induced cytotoxicity and oxidative stress. According to our findings, the protective effect of both extracts is due to their antioxidant activity. Also, the inhibition of AChE enzyme by the extracts might be involved. Both extracts attenuated $A \beta$-induced cell death by ameliorating oxidative stress. Based on these findings, $C$. microcarpa and A. scoparia extracts may have therapeutic effects on Alzheimer's disease. However, further investigations are recommended.

\section{Acknowledgments}

This study was a part of an MSc thesis financially supported by Tarbiat Modares University.

\section{Conflict of Interest}

Authors declared no conflict of interest.

\section{References}

1. Selkoe DJ, Hardy J. The amyloid hypothesis of Alzheimer's disease at 25 years. EMBO Mol Med. 2016;8(6):595-608.

[DOI:10.15252/emmm.201606210]

2. De Strooper B, Karran E. The cellular phase of Alzheimer's disease. Cell. 2016;164(4):603-15. [DOI:10.1016/j.cell.2015.12.056]

3. Irvine GB, El-Agnaf OM, Shankar GM, Walsh DM. Protein aggregation in the brain: The molecular basis for Alzheimer's and Parkinson's diseases. Molec Med. 2008;14(7):451-64. [DOI:10.2119/200700100.Irvine]

4. Sun X, Chen WD, Wang YD. Beta-Amyloid: the key peptide in the pathogenesis of Alzheimer's disease. Front Pharmacol. 2015;6:221. [DOI:10.3389/fphar.2015.00221]

5. Huang X, Atwood CS, Hartshorn MA, et al. The A beta peptide of Alzheimer's disease directly produces hydrogen peroxide through metal ion reduction. Biochem. 1999;38(24):7609-16 [DOI:10.1021/bi990438f]

6. Zhu X, Su B, Wang X, Smith MA, Perry G. Causes of oxidative stress in Alzheimer disease. Cell and Molec Life Sci. 2007;64(17):2202-10. [DOI:10.1007/s00018-007-7218-4]

7. Cheignon $\mathrm{C}$, Tomas $\mathrm{M}$, Bonnefont-Rousselot D, Faller P, Hureau C, Collin F. Oxidative stress and the amyloid beta peptide in Alzheimer's disease. Redox
Biol. $2018 ; 14: 450-64$

[DOI:10.1016/j.redox.2017.10.014]

8. Ferreira ME, de Vasconcelos AS, da Costa Vilhena $\mathrm{T}$, et al. Oxidative stress in Alzheimer's disease: Should we keep trying antioxidant therapies? Cell Molec Neurobiol. 2015;35(5):595-614. [DOI:10.1007/s10571-015-0157-y]

9. Li FJ, Shen L, Ji HF. Dietary intakes of vitamin E, vitamin $\mathrm{C}$, and beta-carotene and risk of Alzheimer's disease: a meta-analysis. J Alzheimer's Dis. 2012;31(2):253-8. [DOI:10.3233/JAD-2012120349]

10. Gustafson DR, Clare Morris M, Scarmeas N, et al. New perspectives on Alzheimer's disease and nutrition. J Alzheimer's Dis. 2015;46(4):1111-27. [DOI:10.3233/JAD-150084]

11. Amato A, Terzo S, Mule F. Natural compounds as beneficial antioxidant agents in neurodegenerative disorders: A focus on Alzheimer's disease. Antioxidants. 2019;8(12). [DOI:10.3390/antiox8120608]

12. Deardorff WJ, Feen E, Grossberg GT. The use of cholinesterase inhibitors across all stages of Alzheimer's disease. Drugs \& Aging. 2015;32(7):537-47. [DOI:10.1007/s40266-0150273-x]

13. Batool A, Kamal MA, Rizvi SMD, Rashid S. Topical discoveries on multi-target approach to manage Alzheimer's disease. Curr Drug Metab. 2018;19(8):704-13. [DOI:10.2174/1389200219666180305152553]

14. Ambure P, Bhat J, Puzyn T, Roy K. Identifying natural compounds as multi-target-directed ligands against Alzheimer's disease: an in silico approach. J Biomolec Struct \& Dynamics. 2019;37(5):1282-306. [DOI:10.1080/07391102.2018.1456975]

15. Schulz V, Hänsel R, Blumenthal M, Tyler VE. Rational phytotherapy: A reference guide for physicians and pharmacists: Springer Science \& Business Media; 2004. [DOI:10.1007/978-3-66209666-6]

16. Hamaguchi T, Ono K, Murase A, Yamada M. Phenolic compounds prevent Alzheimer's pathology through different effects on the amyloid- $\beta$ aggregation pathway. Am J Pathol. 2009;175(6):2557-65. [DOI:10.2353/ajpath.2009.090417]

17. Golkar A, Nasirpour A, Keramat J. $\beta$-lactoglobulinAngum gum (Amygdalus Scoparia Spach) complexes: Preparation and emulsion stabilization. J Disper Sci Technol. 2015;36(5):685-94. [DOI:10.1080/01932691.2014.919587]

18. Hashemnia M, Nikousefat Z, Yazdani-Rostam M. Antidiabetic effect of Pistacia atlantica and Amygdalus scoparia in streptozotocin-induced 
diabetic mice. Compar Clin Pathol. 2015;24(6):1301-6. [DOI:10.1007/s00580-0152068-1]

19. Mosaddegh M, Naghibi F, Moazzeni H, Pirani A, Esmaeili S. Ethnobotanical survey of herbal remedies traditionally used in Kohghiluyeh va Boyer Ahmad province of Iran. J Ethnopharmacol. 2012;141(1):80-95.

[DOI:10.1016/j.jep.2012.02.004]

20. Hajimehdipoor H, Ara L, Moazzeni H, Esmaeili S. Evaluating the antioxidant and acetylcholinesterase inhibitory activities of some plants from Kohgiluyeh va Boyerahmad province, Iran. Res J Pharmacog. 2016;3(4):1-7.

21. Soodi M, Hajimehdipoor H, Ataei N, Akbari S. Study of theprotective effects of seven Iranian medicinal plant extracts against Beta-Amyloid induced cytotoxicity in PC12 Cells. Pathobiol Res. 2016;19(3):45-58.

22. Contestabile A. Cerebellar granule cells as a model to study mechanisms of neuronal apoptosis or survival in vivo and in vitro. Cerebellum. 2002;1(1):41-55.

[DOI:10.1080/147342202753203087]

23. Wei H, Leeds PR, Qian Y, Wei W, Chen R-w, Chuang D-M. $\beta$-Amyloid peptide-induced death of PC 12 cells and cerebellar granule cell neurons is inhibited by long-term lithium treatment. Europ J Pharmacol.

2000;392(3):117-23. [DOI:10.1016/S0014-2999(00)00127-8]

24. Soodi M, Dashti A, Hajimehdipoor H, Akbari S, Ataei N. Melissa officinalis acidic fraction protects cultured cerebellar granule neurons against beta amyloid-induced apoptosis and oxidative stress. Cell J. 2017;18(4):556.

25. Sylvester PW. Optimization of the tetrazolium dye (MTT) colorimetric assay for cellular growth and viability. Drug design and discovery: Springer; 2011. p. 157-68. [DOI:10.1007/978-1-61779-012-6_9]

26. Wang H, Joseph JA. Quantifying cellular oxidative stress by dichlorofluorescein assay using microplate reader. Free Radical Biol Med. 1999;27(5-6):612-6. [DOI:10.1016/S0891-5849(99)00107-0]

27. Bradford MM. A rapid and sensitive method for the quantitation of microgram quantities of protein utilizing the principle of protein-dye binding. Analytic Biochem. 1976;72(1-2):248-54. [DOI:10.1016/0003-2697(76)90527-3]

28. Ellman GL, Courtney KD, Andres V, Feather-Stone RM. A new and rapid colorimetric determination of acetylcholinesterase activity. Biochem Pharmacol. 1961;7:88-95. [DOI:10.1016/0006-2952(61)901459]

29. Naoi M, Shamoto-Nagai M, Maruyama W. Neuroprotection of multifunctional phytochemicals as novel therapeutic strategy for neurodegenerative disorders: Antiapoptotic and antiamyloidogenic activities by modulation of cellular signal pathways. Future Neurol. 2019;14(1):FNL9. [DOI:10.2217/fnl2018-0028]

30. Camilleri A, Zarb C, Caruana M, et al. Mitochondrial membrane permeabilisation by amyloid aggregates and protection by polyphenols. Biochimica et biophysica acta. 2013;1828(11):2532-43. [DOI:10.1016/j.bbamem.2013.06.026]

31. Naoi M, Wu Y, Shamoto-Nagai M, Maruyama W. Mitochondria in neuroprotection by phytochemicals: Bioactive polyphenols modulate mitochondrial apoptosis system, function and structure. Int J Molec Sci. 2019;20(10):2451.

[DOI:10.3390/ijms20102451]

32. Arancibia S, Silhol M, Moulière F, et al. Protective effect of BDNF against beta-amyloid induced neurotoxicity in vitro and in vivo in rats. Neurobiol Dis. 2008;31(3):316-26. [DOI:10.1016/j.nbd.2008.05.012]

33. Mansuri ML, Parihar P, Solanki I, Parihar MS Flavonoids in modulation of cell survival signalling pathways. Genes Nutr. 2014;9(3):400. [DOI:10.1007/s12263-014-0400-z]

34. Murray AP, Faraoni MB, Castro MJ, Alza NP, Cavallaro V. Natural AChE inhibitors from plants and their contribution to Alzheimer's disease therapy. Current Neuropharmacol. 2013;11(4):388-413. [DOI:10.2174/1570159X11311040004]

35. Roseiro LB, Rauter AP, Serralheiro MLM. Polyphenols as acetylcholinesterase inhibitors: structural specificity and impact on human disease. Nutrition and Aging. 2012;1(2):99-111. [DOI:10.3233/NUA-2012-0006]

36. dos Santos TC, Gomes TM, Pinto BAS, Camara AL, de Andrade Paes AM. Naturally occurring acetylcholinesterase inhibitors and their potential use for Alzheimer's disease therapy. Front Pharmacol. 2018;9. [DOI:10.3389/fphar.2018.01192]

37. Moran M, Mufson E, Gomez-Ramos P. Colocalization of cholinesterases with $\beta$ amyloid protein in aged and Alzheimer's brains. Acta Neuropathologica. 1993;85(4):362-9. [DOI:10.1007/BF00334445]

38. Inestrosa NC, Alvarez A, Perez CA, et al. Acetylcholinesterase accelerates assembly of amyloid-beta-peptides into Alzheimer's fibrils: possible role of the peripheral site of the enzyme. Neuron. 1996;16(4):881-91. [DOI:10.1016/S08966273(00)80108-7]

39. Alvarez A, Alarcón R, Opazo C, et al. Stable complexes involving acetylcholinesterase and amyloid- $\beta$ peptide change the biochemical properties of the enzyme and increase the neurotoxicity of 
Alzheimer's fibrils. J Neurosci. 1998;18(9):3213-23. [DOI:10.1523/JNEUROSCI.18-09-03213.1998]

40. Soodi M, Saeidnia S, Sharifzadeh M, et al. Satureja bachtiarica ameliorate beta-amyloid induced memory impairment, oxidative stress and cholinergic deficit in animal model of Alzheimer's disease. Metab Brain Dis. 2016;31(2):395-404. [DOI:10.1007/s11011-015-9773-y]

41. Sberna G, Sáez-Valero J, Beyreuther K, Masters CL, Small DH. The amyloid $\beta$-protein of Alzheimer's disease increases acetylcholinesterase expression by increasing intracellular calcium in embryonal carcinoma P19 cells. J Neurochem.
1997;69(3):1177-84. 4159.1997.69031177.x]

[DOI:10.1046/j.1471-

42. Härtl R, Gleinich A, Zimmermann M. Dramatic increase in readthrough acetylcholinesterase in a cellular model of oxidative stress. J Neurochem. 2011;116(6):1088-96. [DOI:10.1111/i.14714159.2010.07164.x]

43. Sepand MR, Soodi M, Hajimehdipoor H, Soleimani M, Sahraei E. Comparison of neuroprotective effects of Melissa officinalis total extract and its acidic and non-acidic fractions against A Beta-Induced toxicity. Iran J Pharmaceut Res. 2013;12(2):415-23.

\section{How to Cite This Article:}

\section{J Adv Med Biomed Res. 2020; 28 (126) :23-32}

\section{Download citation:}

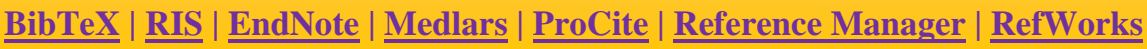

\section{Send citation to:}

Mendeley $2 \underline{\text { Zotero }}$ 目RefWorks $\underline{\text { RefWorks }}$ 